\title{
Ethno-genetics of AIM1 gene relating to Human Skin Pigmentation among Six Indigenous Nationalities in Nepal
}

\author{
Nanda Bahadur Singh ${ }^{1,2}$ \\ ${ }^{1}$ Unit of Human Biology and Genetics, Department of Biological Sciences \\ School of Science, University of Tokyo, Japan \\ ${ }^{2}$ Central Department of Zoology, T. U. Kathmandu, Nepal \\ Email:nanda_nepal@yahoo.com
}

\begin{abstract}
This paper attempts to find out allele frequencies of AIM1 gene among six ethnic groups in Nepal by detecting a total number of 456 blood and nail samples through an allele specific PCR amplification. The research findings revealed that the AIM1 codon L374F polymorphism distinctively showed conspicuous ethnic distribution of the two alleles; namely allele "F" was found mostly high (11.4\%) in the Caucasoid Chidimar and rarely low (1.1\%) in the Dravidian Munda whereas Mongoloid Chepang, Gurung, Raute and Thakali entirely lacked the " $F$ " allele and showed the monomorphic type for the "L" allele. The codon L374F could be the best genetic marker for distinguishing Caucasian populations from Mongoloid ones and would explain the ethno-genomics of human skin coloration among many ethnic groups in the world.
\end{abstract}

Keywords: Human skin pigmentation, melanoma, polymorphism

\section{INTRODUCTION}

Human antigen in melanoma (AIM1) differs from the Ser/Thr kinase, also called "AIM-1 located on the human chromosome 17 (Katayama et al. 1998) and that of the mouse absent in melanoma gene (aim1) found on the mouse chromosome 10 (Teichmann et al. 1998). The medaka-fish homologue, also known as AIM-1, was found to be 55 percent identical to Human AIM1 (Fukamachi et al. 2001). The mouse underwhite locus (uw-locus) gene was renamed as membrane-associated transporter protein (Matp) and its human homologue as MATP (Xu et al. 2012). The human AIM1 gene known alternatively as MATP was mapped to chromosome 5p (Newton et al. 2001). AIM1 protein identified as an antigen in human melanoma encodes a protein of 530 amino acids (Harada et al. 2001). The main function of AIM1 as a transporter in melanin synthesis has been suggested by its 12-domain membrane pass sharing similarity with the structure of the sucrose transporter in plants (Fukamachi et al. 2001).

There is not known sucrose transporter in mammals, it is feasible that MATP co-transports a sugar molecule with a proton. MATP protein plays a critical role in vertebrate pigmentation, presumably mediating the transport of a critical substance across the melanosome membrane (Newton et al. 2001, Graf et al. 2007, Guedj et al. 2008). The most common AIM1 codon L374F polymorphism was identified in the MATP coding sequencing corresponding to the exon 5 in the normally pigmented individuals (Newton et al. 2001, Yuasa et al. 2006, Bin et al. 2015). For the first time, this polymorphism was used in our laboratory to investigate the genetic variation among the representatives of major human populations with varying degrees of skin pigmentations (Nakayama et al. 2002, Stokowski et al. 2007, Graf et al. 2007). This prompted me to use AIM1 codon L374F polymorphism as a newly identified human genetic marker for skin color to investigate among six Nepalese ethnic groups with different skin pigmentations. In this context, this study attempts to find out allele frequencies of AIM1 gene among six ethnic groups in Nepal.

\section{MATERIALS AND METHODS}

Altogether 456 samples belonging to six Nepalese ethnic groups were subjected to genotyping for detecting the frequency of the AIM1 gene L374F polymorphism (Table $1 \&$ Fig. 1). NaI method was implemented to extract DNA from the whole blood, Phenol-Chloroform method was used to extract DNA from the cultured cells and modified method was used to extract DNA from nail samples. 


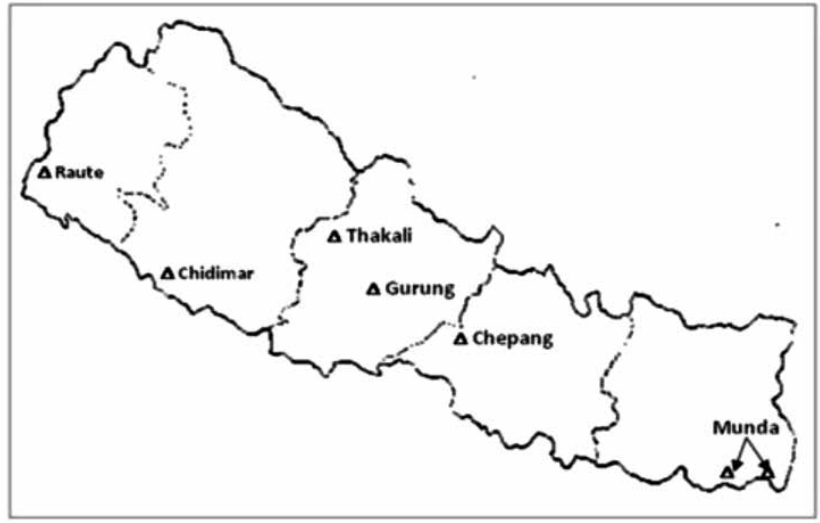

Fig. 1. Map and location of Nepalese indigenous nationalities.

One time PCR amplification was performed using allele specific two forward primers and a universal reverse primer, namely L374 \& F374 (5'-TTGGATGTTGGGGCTTG-3' \& 5'-TTGGATGTTGGGGCTTC-3') and (5'-TCCCTTTCATTTTCCAGAGA-3'); respectively (Nakayama et al. 2002). The underline base near the 3' end of forward primer was mutant-specific substitution. This allele specific PCR was carried out to identify L374F genotypes (Fig. 2b).
Components of PCR reaction were PCR buffer I (Applied Biosystems, Japan), $1.5 \mathrm{mM} \mathrm{MgCl}, 0.2 \mathrm{mM}$ each dNTP, $0.4 \mathrm{pM} / \mathrm{ul}$ reverse and forward primer, and 0.03 unit/ul AmpliTaq Gold (Applied Biosystems).

The conditions for the PCRs were an initial denaturation at $95^{\circ} \mathrm{C}$ for $9 \mathrm{~min}, 40$ cycles of $94^{\circ} \mathrm{C}$ for $30 \mathrm{sec}, 60^{\circ} \mathrm{C}$ for $30 \mathrm{sec}$ and $72^{\circ} \mathrm{C}$ for $1 \mathrm{~min}$ with additional extension at $72^{\circ} \mathrm{C}$ for $5 \mathrm{~min}$ in the last cycle.

There were two PCR reaction mixtures for each sample for wild and mutant type forward primers with a universal reverse primer. After allele specific PCR, the PCR products were $317 \mathrm{bp}$ single fragments were visualized by 2.5 percent agarose gel electrophoresis followed by staining with ethidium bromide and photos were taken by the printgraph (Bioinstrument Atto, Japan). Lanes 1 and 2 were genotyped in two reaction mixtures as wild type. But lanes 3 and 4 were genotyped as heterozygous and lanes 5 and 6 as the mutant homozygous; respectively (Fig. 2). Finally, allele frequencies of the AIM1 codon L374F polymorphism among Nepalese ethnic groups were calculated by the use of Hardy-Weinberg formula for analysis and interpretation.

\section{RESULTS}

Fig. 2 revealed the genomic structure of the AIM1 gene with total 7 exons constituted from Newton et al. (2001).

(a)

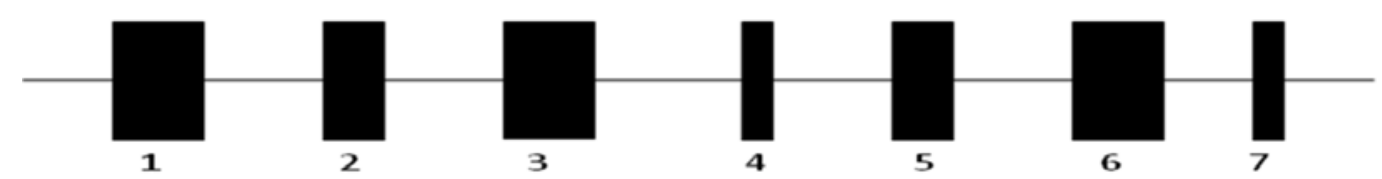

(b)



Fig. 2. AIM1 gene analysis: (a) Genomic structure of the AIM1 gene with 7 exons constituted from Newton et al.(2001). (b) Designing the allele specific primer set flanking AIM1 codon L374F polymorphism in the exon 5.

Fig. 3 depicted the designing the allele specific primer set flanking AIM1 codon L374F polymorphism in the exon 5. It was the product of the different lane patterns with a single band (317 bp) after performing allele specific PCR. Lane 1 was only amplified but not the lane 2 for the wild type. Both the lanes 3 and 4 were amplified for the wild as well as mutant type for heterozygous. Lane 5 was not amplified for wild type but the lane 6 for the mutant type. Therefore, without using restriction enzyme, genotyping of different ethnic groups could be done by allele specific PCR amplification. 


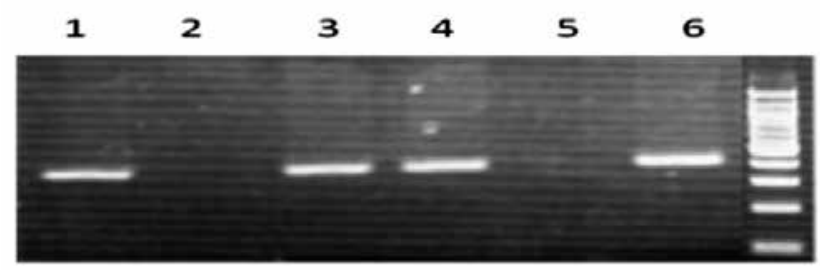

Fig. 3. PCR-RFLP products of the AIM1 gene: PCR Products of AIM1 codon L374F polymorphism in the exon 5 generated by allele specific PCR. A 317 bp single fragment was visualized on 2.5 percent agarose gel electrophoresis followed by staining with ethidium bromide. Genotypes were recognized by allele specific PCR. Each sample contained double lanes. Lanes 1 and 2: wild; lanes 3 and 4: heterozygous; lanes 5 and 6: homozygous types.

Table 1 shows the allele frequencies of the AIM1 codon L374F polymorphism genotyped among six Nepalese ethnic groups. This polymorphism is controlled by two alleles, leucine (L) and phenylalanine (F); respectively.

Table 1. Allele frequencies of AIM1 Codon L373F among 6 different ethnic groups in Nepal

\begin{tabular}{|l|l|c|c|c|}
\hline \multirow{2}{*}{$\begin{array}{c}\text { Ethnic } \\
\text { groups }\end{array}$} & \multirow{2}{*}{$\begin{array}{c}\text { Locality } \\
\text { (District) }\end{array}$} & \multirow{2}{*}{ Population } & \multicolumn{2}{|c|}{$\begin{array}{c}\text { Allele frequency } \\
\text { of }\end{array}$} \\
\cline { 4 - 5 } & & 72 & 1.000 & 0.000 \\
\hline Chepang & Chitwan & 35 & 0.886 & 0.114 \\
\hline Chidimar & Banke & 68 & 1.000 & 0.000 \\
\hline Gurung & $\begin{array}{l}\text { Kaski and } \\
\text { Shyangja }\end{array}$ & 88 & 0.989 & 0.011 \\
\hline Munda & $\begin{array}{l}\text { Jhapa and } \\
\text { Morang }\end{array}$ & 102 & 1.000 & 0.000 \\
\hline Raute & Dadeldhura & 1 & 1.000 & 0.000 \\
\hline Thakali & $\begin{array}{l}\text { Mustang and } \\
\text { Myagdi }\end{array}$ & 91 & & \\
\hline
\end{tabular}

The AIM1 codon L374F polymorphism distinctively showed conspicuous ethnic distribution of the two alleles. The allele " $F$ " was found mostly in the Caucasoid Chidimar and rarely in the Dravidian Munda. Its frequency ranged from the highest 11.4 percent in the Chidimar to 1.1 percent in the Munda whereas Mongoloid Chepang, Gurung, Raute and Thakali entirely lacked the "F" allele and showed the monomorphic type for the "L" allele. The result segregated the Caucasoid from the Mongoloid ethnic groups with a little chance of genetic admixture of the Munda with the Caucasians.

\section{DISCUSSION AND CONCLUSION}

Graf et al. (2005) found a significant association between 2 polymorphisms of the MATP gene in Caucasians, an 814G-A transition resulting in a glu272-to-lys substitution $(\mathrm{G} 272 \mathrm{~K})$ and an $1122 \mathrm{C}-\mathrm{G}$ trans-version resulting in a phe374-to-leu substitution (F374L). The systematic ethnic study on the distinctive distribution of AIM1 codon L374F polymorphism was firstly carried out among White South African, Ghanaian, Japanese and New Guinea Islanders with a contrast of skin pigmentation (Newton et al. 2001, Yuasa et al. 2006, Bin et al. 2015). The "F" allele was only detected exclusively in White South Africans (89\%) but not at all in all ethnic groups studied (Nakayama et al. 2002). The White South Africans were extremely found to show predominant in the " $F$ " allele. In this aspect, the present study is consistent with the only previous researches on different populations. The Caucasoid oriented blackish Chidimar showed the prevalence of the "F" allele but less in amount (11.4\%) in comparison to White South Africans. Small percentage of the prevalence of the " $F$ " allele in the Munda provided the evidence of its possible genetic admixture with the Caucasians. The codon L374F could be the best genetic marker for distinguishing Caucasian populations from Mongoloid ones and would explain the ethno-genomics of human skin coloration among many ethnic groups. The genetic variation for skin color background will be fascinating, if ethnic populations are closely watched from Nigeria to Norway and Bali to Italy.

\section{ACKNOWLEDGEMENTS}

I am gratified by Prof. Takafumi Ishida and his team's cooperation for providing me the great opportunity of doing my research at Ishida Laboratory of Unit of Human Biology and Genetics, Department of Biological Sciences, School of Science, University of Tokyo, Japan. I am also thankful to the leaders of six above-mentioned indigenous nationalities for their due cooperation during my field visits.

\section{REFERENCES}

Bin B.H., Bhin J, Yang S.H., Shin M., Nam Y.J., Choi D.H., Shin D.W., Lee A.Y., Hwang D., Cho E.G., Lee T.R. 2015. Membrane-Associated Transporter Protein (MATP) Regulates Melanosomal pH and Influences Tyrosinase Activity. PLoS One (Jun 9): 10 (6).

Fukamachi, S., Shimada, A., Shima, A. 2001. Mutations in the gene encoding B, a novel transporter protein, reduce melanin content in medaka. Nature Genet 28: $381-385$.

Graf, J., Hodgson, R., van Daal, A. 2005. Single nucleotide polymorphisms in the MATP gene are associated with normal human pigmentation variation. Hum. Mutat. 25: 278-284.

Graf, J., Voisey, J., Hughes, I., van Daal, A. 2007. Promoter polymorphisms in the MATP (SLC45A2) gene are associated with normal human skin color variation. Hum. Mutat. 28: 710-717. 
Guedj, M., Bourillon, A., Combadieres, C., Rodero, M., Dieude, P., Descamps, V., Dupin, N., Wolkenstein, P., Aegerter, P., Lebbe, C., Basset-Seguin, N., Prum, B., Saiag, P., Grandchamp, B., Soufir, N. 2008. Variants of the MATP/SLC45A2 gene are protective for melanoma in the French population. Hum. Mutat. 29: 1154-1160.

Harada, M., Li, Y.F., El-Gamil, M., Rosenberg, S.A., Robbins, P.F. 2001. Use of an in vitro immunoselected tumor line to identify shared melanoma antigens recognized by HLA-A*0201restricted Tcells. CancerRes. 61: 1089-1094.

Katayama, H., Ota, T., Morita, K., Terada, Y., Suzuki, F., Katoh, O., Tatsuka, M. 1998. Human AIM1: cDNA cloning and reduced expression during endomitosis in megakaryocyte-lineage cells. Gene 224: 1-7.

Nakayama, K., Fukamachi, S., Kimura, H., Koda,Y., Soemantri, A., Ishida, T. 2002. Distinctive distribution of AIM1 polymorphism among major human populations with different skin color. $J$ Hum Genet. 47: 92-94.

Newton, J.M., Cohen-Barak, O., Hagiwara, N., Gardner, J.M., Davisson, M.T., King, R.A., Brilliant, M.H. 2001. Mutations in the human orthologue of the mouse underwhite gene (uw) underlie a new form of oculocutaneous albinism, OCA4. Am. J. Hum. Genet. 69: 981-988.
Stokowski, R.P., Pant, P.V.K., Dadd, T., Fereday, A., Hinds, D.A., Jarman, C., Filsell, W., Ginger, R.S., Green, M.R., van der Ouderaa, F.J., Cox, D.R. 2007. A genome-wide association study of skin pigmentation in a South Asian population. Am. J. Hum. Genet. 81: 1119-1132.

Teichmann, U., Ray, M.E., Ellison, J., Graham, C., Wistow, G., Meltzer, P.S., Trent, J.M., Pavan, WJ (1998): Cloning and tissue expression of the mouse ortholog of AIM1, a betagammacrystallin superfamily member. Mamm Genome 9: 715-720.

Xu, B., Pang T., Yao C.Q., Zhang L.Y., Zheng H., Jiang W.Y., Li, H.Y. 2012. Identification of a novel pathogenic mutation in MATP gene with oculocutaneous albinism type IV from a consanguineous marriage family. Zhonghua $\mathrm{Yi}$ Xue Za Zhi. 92(4): 254-258.

Yuasa, I., Umetsu, K., Harihara, S., Kido, A., Miyoshi, A., Saitou, N., Dashnyam, B., Jin, F., Lucotte, G., Chattopadhyay, P.K., Henke, L., Henke, J. 2006. Distribution of the F374 allele of the SLC45A2 (MATP) gene and founder-haplotype analysis. Ann. Hum. Genet. 70: 802-811. 